\title{
La imagen del niño en la sociedad de la imagen
}

MJ. Esparza Olcina

Pediatra. CS Barcelona. Móstoles, Madrid. España.

La sociedad actual puede decirse que es la sociedad de la imagen. Las pantallas tienen un gran protagonismo en los hogares, y no siempre nos gusta la imagen de los niños que nos devuelven. Los medios de comunicación escritos, lamentablemente, tienen muchísimo menos impacto en una gran mayoría de familias en nuestro país, por lo que es la imagen del niño en la televisión, sobre todo, la que dibuja lo que es el niño en la sociedad actual. Pero cuidado, ¿el niño es ese ser consumista, adultizado prematuramente que vemos con frecuencia? No, esa imagen del niño no es justa.

Se transgrede con frecuencia la legislación relacionada con el uso de la imagen del niño en la publicidad y también la legislación sobre la protección de la intimidad del menor. Todo vale con tal de tener mayor audiencia, vender más objetos $\mathrm{y}$, lo que es más lamentable, vender más alimentos hi- percalóricos de bajo valor nutritivo pero muy atractivos.

En este número de la Revista Pediatría de Atención Primaria (Revista PAP) queremos atraer la atención sobre este importantísimo asunto: la imagen del niño. Es un tema que se podría tratar desde muchos puntos de vista: educativos, estéticos, legislativos, filosóficos, éticos, culturales, artísticos, etc.

En el anterior número de la Revista PAP se repasó en su editorial la visión del niño desde el mundo del arte ${ }^{1}$ y se dio así por inaugurada una nueva sección sobre este tema. En este número, para abordar la imagen del niño desde otros puntos de vista, traemos dos colaboraciones muy interesantes; una de ellas habla sobre el tratamiento legal de la imagen del niño y otra sobre la imagen del niño en el cine.

Como nos describe con detalle Juan $\mathrm{Siso}^{2}$, la protección de la intimidad es el principal objetivo del tratamiento de la

Ma . Jesús Esparza Olcina: mjesparza@pap.es 
imagen del niño en la legislación, objetivo muy necesario en el mundo del siglo XXI en que la velocidad y la amplitud de la difusión de las imágenes puede suponer una gravísima agresión de importantes consecuencias para el menor.

La gran pantalla, el cine, donde podemos ver ficción y realidad, nos puede mostrar una infancia con mil caras, tantas $\mathrm{y}$ tan variadas como directores $\mathrm{y}$ guionistas. Puede ser una imagen amable e ingenua, puede ser la de una infancia que sufre, la del éxito y la fama, también una imagen ficticia, pero los espectadores sabemos que lo es. El cine cuenta historias y lo más probable es que los espectadores las incorporemos de este modo, como historias que han sucedido o que podrían suceder (por lo menos hoy en día, ya que en determinadas épocas el cine tenía también una función ejemplificadora, con un ideario concreto). Lo que quiero expresar es que el cine no nos hace daño, no nos invade como lo hace la pequeña pantalla, vamos a verlo, no se entromete en nuestra intimidad como lo hace la publicidad o lo pueden hacer (si les dejamos) determinados programas televisivos. Es un mundo fascinante que nos es relatado en una colaboración especial, dividida en dos capítulos, ambos en este número de la Revista $\mathrm{PAP}^{3,4}$, que nos abre los ojos a las grandes posibilidades didác- ticas que tiene el cine. Suscribo las palabras de Javier González de Dios cuando dice: "Con la imagen todo es directo, rápido, como un atajo que despierta la emoción. El cine provoca emociones $y$, sobre todo, ofrece la posibilidad de contemplarlas y compartirlas en discusión abierta, abriendo caminos para una verdadera reconstrucción afectiva". Y es que el autor nos habla del cine no sólo como espectáculo, sino como una herramienta con capacidad de educar, de hacer pedagogía, de darnos imágenes sobre las que discutir y extraer conclusiones. Puede ser una herramienta de gran ayuda, como él nos comenta, en la docencia de los médicos, ya que el cine no ve enfermedades sino enfermos, personas en su entorno, con sus problemas, su familia, su carga cultural y social. Hace que nos pongamos en el "otro lado", es comparable a la experiencia que como médicos deberíamos todos experimentar, de estar en una sala de espera, como pacientes, escuchando los comentarios de los demás enfermos; se aprende mucho.

Otro aspecto de la imagen del niño que no queremos pasar por alto es la publicitaria. Sólo apuntar en breves palabras que hemos podido percibir cómo las técnicas publicitarias han ido sustituyendo la imagen de la mujer por la del niño, movidas por el deseo de ser políti- 
camente correctas, evitar las protestas de los grupos feministas o simplemente de las mujeres actuales, o por lo menos intentarlo. Así que han encontrado el filón: utilizar a los niños en la publicidad, ellos no se quejan ${ }^{5}$.

Como responsables de la salud de los niños en su concepto más amplio, debe- mos los pediatras velar por que los niños sean representados en los medios con respeto, salvaguardando su intimidad, y ateniéndose a las normas legislativas que les protegen. Si esto no es así, deberemos hacer público nuestro desacuerdo y hacernos oír en las instancias que correspondan.

\section{Bibliografía}

1. Carabaño Aguado I. ¿Por qué los artistas se interesan por los niños? Rev Pediatr Aten Primaria. 2010;12:11-3.

2. Siso Martín J. La imagen del niño; su tratamiento legal. Rev Pediatr Aten Primaria. 2010; 12:287-95.

3. González de Dios J. Cine y Pediatría (I): una oportunidad para la docencia y la humanización en nuestra práctica clínica. Rev Pediatr Aten Primaria. 2010;12:299-313.

4. González de Dios J. Cine y Pediatría (II): infancia y adolescencia en las pantallas de cine de todo el mundo. Rev Pediatr Aten Primaria. 2010;12:e21-e46.

5. Ortiz Tardío J. El niño, los medios y la publicidad. Vox Paediatrica. 2008;16:39-43. 